\title{
'Gaafa dhaabaa - the period of stop': Narrating impacts of shifta insurgency on pastoral economy in northern Kenya, c. 1963 to 2007
}

Zeinabu Kabale Khalif ${ }^{1}$ and Gufu Oba ${ }^{1,2^{*}}$

* Correspondence: gufu.oba@umb.no

'Department of International Environment and Development Studies (NORAGRIC), Norwegian University of Life Sciences, P.O. Box 5003, Ås 1432, Norway

International Peace Research Institute (PRIO), Oslo 0134, Norway

\begin{abstract}
In northern Kenya, there have been limited discussions on the impacts of the 1960 to 1968 insurgency wars and subsequent banditry on the long-term impacts of the pastoral economy. This is despite the societies' vivid memories of the effects of these wars, from which research would gain a long-term outlook about consequences on rural economies. We present an understanding of the long-term impact of the shifta (term used at that period by the Kenyan Government) for the secessionist war fought by the Somali insurgents with the armed forces of Kenya between 1963 and 1968. We evaluate the impact of the shifta insurgency, the army's counter-insurgency and the subsequent insecurity on the recovery of the pastoral economy between 1984 and 2007. We interviewed members of three communities in Isiolo District in Kenya affected by the shifta war. The research shows that the livestock herds of the communities have not achieved the levels of recovery of the pre-shifta war forty-four years after that conflict ended. Persistent banditry and recurrent droughts are blamed by the pastoralists for the lack of recovery of the pastoral herds of the three communities. The article concludes that armed conflicts, coupled with risks of droughts, have a long-term impact on the pastoral economy.
\end{abstract}

Keywords: Conflicts, Counter-insurgency, Insurgency, Horn of Africa, NFD, Pastoral economic collapse, shifta, Waso Borana

\section{Introduction}

Contemporary scholarship on pastoral conflicts in the Horn of Africa suggests that raids and cattle rustlings have contributed to the demise of pastoralism (see Markakis 1993, 1998, 2010; McCabe 2004; Kaimba et al. 2011; Mkutu 2006, 2008). The drivers of the conflicts have been identified as famine, poverty and issues of livestock wealth redistribution (Hendrickson et al. 1996; Buchanan-Smith and Lind 2005), state policies in general (Oba 1993), the politics of identity changes (Schlee and Watson 2009), competition over scarce resources (Schilling et al. 2012) and regional political instability (de Waal 1997; Hammond 1999; Brons 2001). Research on the long-term impact of border wars, insurgencies and counter-insurgencies on the rural economy is however lacking. Insurgency wars have geopolitical linkages, often transferring national and international conflicts onto the local level, with a consequential destructive impact on the rural economy (Miall 2004; Mburu 2005; Whittaker 2012) and population 
displacements (James 2007). We seek an understanding here on the impact of insurgency and the army's counter-insurgency wars on pastoral economies in the former Northern Frontier District (NFD) ${ }^{1}$ of Kenya between 1963 and 1968, and we evaluate the trends of the pastoral economy forty-four years later.

Soon after Kenya's independence in 1963, insurgency and counter-insurgency wars broke out in the NFD with direct impacts on the pastoral populations and their economies (Whittaker 2012). This war was fought by the insurgents of the Northern Frontier District Liberation Front, supported by the Somali Republic (Drysdale 1964; Mburu 2005), against Kenya's security forces. The warring parties targeted the pastoral economy for different reasons. The insurgency group raided herders to get access to food as well as to punish those whom they suspected of opposing secession. The security forces focused their attacks on the same pastoral groups for their alleged sympathy with and practical support for the insurgency. The shifta ${ }^{2}$ war has remained vividly in the memories of local pastoralists, which, in the absence of written historical data, provides an important basis for understanding the effects of insurgency and counter-insurgency wars on a pastoral economy. Yet, we make no a priori assumption that the shifta war alone was responsible for the collapse of the pastoral economy, but rather that it was a major contributing factor.

Firstly, we briefly present the background of the insurgency war. The second aim is to understand how members of some of the communities in which the insurgency took place perceived the impact of the insurgency and counter-insurgency wars on their pastoral economy. The third aim is to evaluate official information on the impact of the insurgency and the army's counter-insurgency on the people and the economy of the Waso Borana pastoralists. The fourth aim is to understand the long-term impact of the common banditry and recurrent droughts on the recovery of the pastoral economy. We begin with brief descriptions of the recent history to place the research into context.

\section{Background}

The historical development of this conflict is beyond the scope of this article. We mention, albeit briefly, the political agitations between Somalia and Kenya (Castagno 1964). The Somali pre-independence agitation inspired the politics of 'Greater Somalia' (Lewis 2000, p. 116). The inspiration of Greater Somalia might have been motivated by 'unusually fortunate' political factors, by which is implied the homogeneity of culture and religion (Lewis 2004, pp. 290 to 291; Hess 1966, pp. 194 to 195). Regional political agitation for Somali unity gathered momentum with the independence of Somalia in 1960. Somalia's grand political plans for uniting all the Somali speakers in the Horn of Africa is enshrined in the constitution and represented in her flag showing a five pointed white star against a sky blue background. The five points represent the five regions in the Horn of Africa that had been split by colonial borders: these included the Ethiopian Ogaden, British Somaliland, the former Italian Somaliland, Djibouti and the Northern Frontier District (NFD) of Kenya (Farer 1979). The Somali national philosophy was well articulated by Mohamed Haji Ibrahim Egal (1968, p. 219), the Prime Minister of the first Somali Republic who stated:

I personally believe that a people living in a country, conditioned to the same elements, exposed to the same hazards, sharing the heritage of democratic traditions, 
bound by language, religion and culture, and linked together by the pursuance of a unique way of life, must inevitably develop similar inhabitations and attitudes as well as a common and unifying philosophical code of ethics and conventions.

The speech by the Somali president Mr. Aden Abdullah Osman at the inaugural summit conference of Organization of African Unity in Addis Ababa in May 1963 was more to the point. He associated imperial boundaries with the political demise of the Somali nomads:

History has shown that the most serious obstacle to African unity originates from the artificial political boundaries which were imposed on large areas of the African continent by colonialist powers. We have seen how traditionally integrated societies were torn apart and how their land is cruelly partitioned [by international borders which in the Somali case run] the entire length of the existing boundaries...cut across the traditional pastures of our own nomadic population (Hoskyns 1969, p. 32).

These were the fundamental principles in the demand for secession by the Somali populations. Yet both Somalia and the neighbouring countries understood the implications of secessionism differently. As McEwen (1971, p. 127) suggests those who supported the secessionist opinion did so on the understanding that they would not be required to move from their present day homes'. Kenya's official expression in the light of the 1960s was that if the population wanted to separate, then they would be at liberty to do so but without an inch of Kenyan soil being transferred to Somalia (Lewis 2000). The Somalia position might be seen from the perspective of the indivisibility of pastures that ecologically and economically determine the very existence of nomads. From the perspective of Kenya, the Somali Republic's policy was a pursuit of territorial claims on her NFD frontier.

This frontier gained prominence in the regional politics when Somali pastoralists resident in the northern area of Kenya expressed a desire for a union with Somalia. In 1960 at a public rally at Mandera in northern Kenya, the governor of Kenya made an oblique statement alluding to the fact that the Kenyan Colonial Government was not in a position to make any guarantees on cession of the province to Somalia 'but would be prepared to assist in the achievement of this object once independence in Kenya was a reality'. The official report added that 'no amount of explanation can now destroy their fond hope that union with Somalia is theirs for the asking'.

During his visit to Mogadishu in 1960, Jomo Kenyatta, the future President of Kenya and leader of the Kenya African National Union and the delegates of the Kenya African Democratic Union, informed the Somali Republic's Prime Minister that the problem of NFD was an 'internal affair in which Somalia was not to interfere'. The Somali Prime Minister responded by stating 'if the phrase "interference in domestic affairs"' was used, then 'any external opposition to Somali reunification is considered as interference in the domestic affairs of the Somali people' (Touval 1972, pp. 213/214). This reprove against the views of the Kenyan delegation was a sign of deteriorating political relationship over the issue of secession.

This did not however stop the colonial government in Kenya from lifting the proscription of the political opposition ${ }^{4}$ (Turton 1972) which increased the political 
temperature in the NFD after the union was formed between the former British Somaliland and Somalia in 1960. The political situation was such that the majority of Somalis in the NFD strongly supported self-determination with the option of uniting with the Somali Republic (Egal 1968). Additionally, in sallying for preparation for the registration of voters for the 1961 general election in Kenya, the Secretary of State for Colonial Affairs, Mr. Reginald Maudling, announced at the 1960 Lancaster House Conference that the views of the NFD residents would be sought on the thorny issue of secession (The Earl of Lytton 1966) against the strong anti-secessionist views of the Kenyan nationalist parties (Drysdale 1964).

The British administration, as promised earlier, called for constitutional arrangements in which different residents of the NFD would present their views. As would be expected, when the population was informed that they were to participate in the preKenyan independence elections, the residents of the NFD (the majority of whom were Somalis) responded violently, displaying their disapproval and showing instead their desire to be united with the newly independent Somali Republic (Turton 1972). Campaigns for self-determination were conducted locally, and delegates were sent to Somalia in 1961 to ask for political and economic support to achieve their objectives 'by all possible means' (Lewis 2000, p. 186).

The Somali National Parliament 'passed a motion supporting the union of [NFD] with the Republic and urging the Government to press for self-determination for its people' (Lewis 1963, p. 58). Similarly, the Somali party delegates at the Lancaster Conference in 1961 announced that they would boycott the forthcoming general election in opposition to the pro-independence Kenyan parties. The views of the Kenyan delegates were strongly expressed by Jomo Kenyatta and Tom Mboya who 'felt that the people of NFD...could not be expected to express a valid opinion until they had an opportunity of fulfilling a more positive role in Kenya's future and expressing the benefits [they would enjoy under] national government' (Drysdale 1964, p. 108). These untenable positions resulted in the Colonial Secretary, Reginald Maudling, proposing a plebiscite 'to ascertain, and report on, public opinion in [NFD]' (Touval 1972, p. 183). The NFD Commission led by three prominent persons was assembled to conduct the plebiscite in the six districts (Mburu 2005).

The Commission completed its findings by December 1962, exactly a year before Kenya's independence. ${ }^{5}$ The Commission arrived at three general conclusions: First, there was a fairly large pro-secessionist population that wished to detach itself from Kenya. Second, there was a pro-Kenya group that had been suspicious of the calls for union with the Somali Republic. Though lacking unity on the matter, the Borana Oromo (the Waso Borana supported the secession) had historical reasons for rejecting the Somali struggle for secession (Baxter 1966). The Rendille and El Molo that supported secessionism had no relationship with the Somalis culturally and historically. The results of the plebiscite were thus divided, forcing the Kenyan Colonial administration to announce in Nairobi the decision for internal self-government within existing boundaries (Mburu 2005). The rejection of secessionism sent shockwaves of political dissent throughout the NFD (The Earl of Lytton 1966).

As anticipated, the outcome was a ruckus by the armed insurgency of the NFPLF against Kenya's security forces and pro-independent pastoral populations. ${ }^{6}$ The outbreak of the war was followed by the looting of livestock, attacks on government 
outposts and assassinations of prominent persons opposed to the secessionist war. The assassinations of the Senior Chief (Haji Galma Dido) and the first African District Commissioner (Mr. Daudi Wabera) by the agents of secession in 1963 (Pieter 1964) were immediately followed by a declaration of a state of emergency throughout the NFD that 'entails the declaration of a five mile wide prohibited zone along the whole of the Kenyan side of the frontier with Somalia' to stop the shifta trained in Somalia from infiltrating across into Kenya (Hoskyns 1969, p. 43).

The outbreak of shifta insurgency from 1963 through to 1967 disrupted life in the NFD, with the brunt of the war affecting the pastoral economy. With the Kenyan leaders expecting a full-scale insurgency, the country's security forces were put on high alert to conduct counter-insurgency (Touval 1972). The security forces considered the whole of the NFD to be an operational area (Mburu 2005). With considerable supplies of military hardware and training being provided by Somalia, the shifta created widespread terror. The government's response to the shifta pressure was to move the pastoralists in the affected areas into 'security villages'. The security clump down was spread in the six districts of NFD (Whittaker 2012). Our focus is on the Isiolo District.

This is the period which the Waso Borana refer to as gaafa dhaabaa ('the period of stop'). They applied the term dhaabaa to describe the 'the stop' of pastoral production and of human liberty. The use of the word dhaabaa implies a break from a past that had been characterised by plentiful pastoral production (gaafa quufa) and by the continuous increase of livestock herds (gaafa hoormaata) to when the pastoral economy had in effect collapsed (gaafa qoolooma) - the period of destitution. By 1966, pastoralists were forced to move to the security villages, mainly in Garbatula, Merti and Madogashe (Figure 1), and their livestock was restricted to a $5-\mathrm{km}$ radius of the camps. Any livestock or people found outside these areas were shot on sight by the police and the military. An estimated 20,000 people and thousands of head of livestock were forced into security settlements (Dahl and Sandford 1978) as a collective punishment and a reaction to the casualties suffered by the Kenyan army to the land mines buried by the insurgency.

Within a short period of time, the economy of the formerly wealthy pastoral population had been shattered. The shifta period had three main consequences: First, the collapse shifted the population from rural areas to local trading centres (Hogg 1980). second, the residual herds had substantially lowered reproductive capacity (Hjort 1979). and third, the impoverished population had become dependent on external food aid and in need of rehabilitation (Hogg 1980, 1985). However, two outcomes, nearly forty years after that war, have not been clearly understood: the status of the pastoral economy and the impacts of sustained banditry.

\section{Study area}

We selected communities living in Kinna, Kulamawe and Merti (Figure 1). The Kinna area serves as a drought reserve for the Waso pastoral production. After the shifta war, the area attracted increased numbers of destitute people from the security settlements. These people had lost all their livestock and were settled on irrigation schemes run by the government and the National Christian Council of Kenya (Hogg 1986). Some of the destitute from Kinna also became internally displaced, forcing them to seek jobs on farms in the neighbouring district of Meru. The community of Kulamawe was 


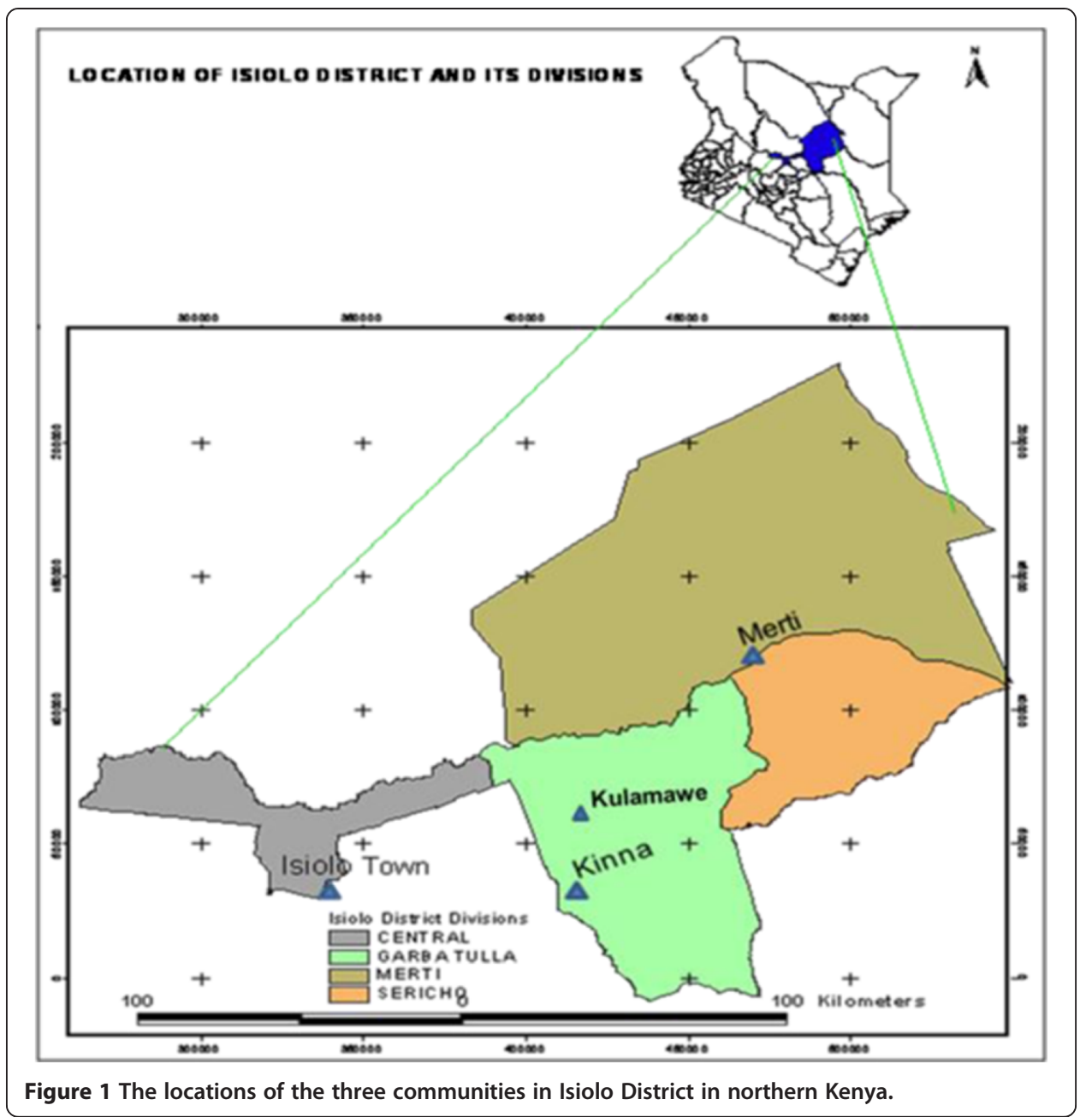

historically renowned for the breeding of small stock and camels, while the Merti community formed part of the Uaso Nyiro River floodplain production system. We conducted a series of interviews in the three communities.

\section{Methodology}

Key informants were selected, mainly elders who were over 60 and older, and in-depth interviews were carried out with 12 key informants from Merti, 15 from Kinna and 10 from Kulamawe. The key informants were knowledgeable about the history of the Waso pastoral production system and had personal experience of the shifta war. Some of the elders selected had participated in the insurgency. Other informants included local security committee agents as well as government security personnel, pastoralists who had fled to Somalia and those who had remained in the security camps. These key informants provided detailed descriptions of Waso pre-shifta pastoral production in terms of the main livelihood strategies of the people. We analysed their narratives on perceptions of the impact of the shifta war on the pastoral economy. We supplemented their information with government sources and newspaper articles.

Additionally, to understand the long-term impact of the shifta war on household livestock holdings, a total of 300 households (60 households from Merti, 120 from 
Kulamawe and 120 from Kinna) were interviewed using a structured questionnaire. They answered questions such as the following: What was the impact of the shifta war on the people? How was livestock production affected by war? Which livestock was most affected? Further, 32 households from Merti, 58 from Kulamawe and 40 from Kinna were interviewed in detail. The informants were asked to report on the estimated numbers by livestock species owned by the family just before the start of the shifta war and at the end of the dhaabaa period in 1968. With the help of the selected family members, the households' livestock holdings for selected years from 1984 to 2007 were reconstructed (here, the family used herd life histories). The selected years were memorable: they were either periods of droughts or heavy rainfall. The aim was to assess the increase in animal numbers, as this might indicate a pastoral recovery since the collapse (i.e. since 1968).

It should however be noted that such recall data are subject to error as a result of memory loss. To minimise this, we interviewed the household heads in the company of their family members so that their memories could be refreshed. The households were asked to report on what they considered to be the major factors that impeded herd growth after the shifta period. In analysing the collapse of the pastoral economy, we calculated the mean estimated livestock holdings for the selected households just before the shifta war, and again in 1968 (at the end of the war), and then calculated the percentage change in terms of the remaining herds in the subsequent years (Figure 2). The term 'recovery" implies that the livestock economy had regenerated to the pre-shifta levels, or, given the magnitude of loss, that the livestock economy had stabilised in comparison with the pre-shifta period. Recovery might also imply herd sizes greater than the residual herds at the end of the conflict in 1968. We made the following additional assumptions regarding livestock recovery: (1) We did not attempt to distinguish the sources of the livestock. (2) We accepted that the total livestock population, comprising different species (i.e. cattle, camels and small stock) per household during the selected periods, irrespective, represented 'herd recovery' or lack of. (3) The extent of recovery was site-specific.

\section{Results and discussion}

\section{Communities' perceptions of the pre-shifta pastoral economy}

The shifta war had major ramifications for the lives and livelihoods of the Waso pastoralists. In the pre-shifta period, the Waso Borana were among the wealthiest pastoral groups in northern Kenya (Baxter 1954). The Waso ecosystem and its pastoral economy were described as follows by a local elder:

Before shifta came to our land, Waso was a land of plenty (lafa quufa)...we had lots of cattle and goats...we were wealthy (nuu dureyii). We also had plenty of meat and milk and people loved each other [too]. ${ }^{8}$

The term quufa describes a state of pastoral wealth and a sense of personal satisfaction. This evaluation was supported by another elder:

In the pre-shifta period...a person with 200 goats or 100 cattle was considered poor...and we had no problems. We were self-sufficient like the [the British]...and we used our land freely....? 

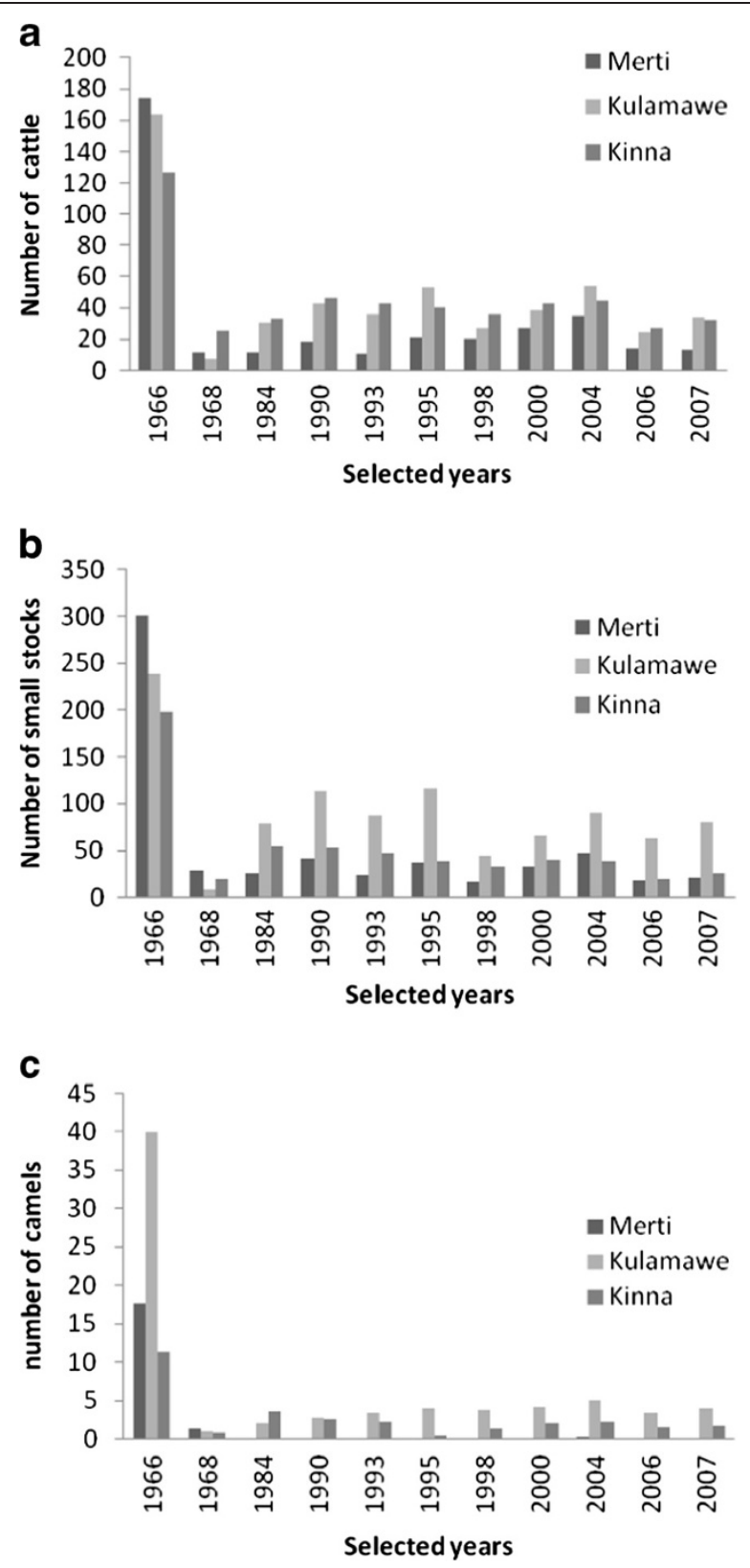

Figure 2 Pre-shifta and post-shifta number of cattle (a), number of small stocks (b) and number of camels (c).

The two observations above portray the pre-shifta Waso Borana as an ideal pastoral society in a number of ways: (1) The community owned large herds of livestock with an abundance of livestock products; this demonstrated high productivity of the pastoral economy. (2) The Waso Borana could migrate with their herds within a large expanse of productive rangeland. The vast grazing areas that were available to them were characterised by important ecological variations, making some grazing areas more suitable for particular types of livestock.

The sampled households confirmed that in the pre-shifta period the Waso Borana were wealthy pastoralists. Even at the time, it is worth noting that the flocks of small stock were 
the largest in terms of numbers per households, with mean populations of 301 animals per household in Merti, 239 in Kulamawe and 198 in Kinna (Figure 2). The cattle holdings were also substantial: In Merti, there was a mean of 174 heads of cattle per household; the smallest herds were found in Kinna, where there were 126 heads per household. In the pre-shifta period, it seems that the camel population was relatively small. The households with the largest camel herds were from Kulamawe, with a mean of 40 animals; those with fewest camels were from Kinna, with a mean of about 11 animals per household. We can thus deduce from the recalled livestock holdings in the pre-shifta period that all three communities had the benefit of a strong pastoral economy.

Baxter (1954) reports that the Waso pastoralists recall moments of prosperity when a few individuals 'even became too foolish' and forgot that living in a risky environment required personal moderation. ${ }^{10}$ Like other pastoralists in the NFD, the Waso Borana had to deal with a highly variable environment, characterised by a 'boom' in production during wet years, when there was a surplus of pastoral products, and a 'slump' during drought years, when production declined. A common view among the herd owners we interviewed was that in the pre-shifta period, the gap between the rich and the poor was minimal because of the high livestock holdings per household that created selfsufficiency. However, this state of pastoral well-being changed during and after the shifta war. We interrogated the communities' perceptions.

\section{Communities' perceptions of the impact of the shifta war}

The Waso Borana suffered the brunt of the onslaught from the insurgency and the Kenyan security's counter-insurgency (Hogg 1980). When the war intensified, the Somali clansmen were able to cross into Somalia with their livestock, while most of the Waso Borana did not have such an opportunity (Hjort 1979). People were arrested and many died as a result of the extra-judicial killings (under the guise of fighting the shifta). The following is one of the narratives by a survivor who lived to tell the story:

The military selected around 70 men from the security camps in Garbatula. We were told we were being taken to Isiolo town to be interrogated on the shifta activities in the area. While we were half way in our journey, in a place called Toiboto, the vehicle was stopped and the military personnel started shooting at us indiscriminately. Some of us who survived jumped out of the vehicle and ran into the nearby bush. Many were not as lucky and at least 47 men were killed that day. The following day there was broadcast on the national radio that shifta were killed by the military... and yet we were innocent civilians. ${ }^{11}$

In Merti, a key informant also reported how some people lost all their family members:

Jirmo Katelo fled to Somalia during the shifta period. While he was away, all members of his family were killed by the military in a day. The total numbers of family members killed were 18; including his wife, children, brothers and his elderly parents. He was the only survivor.... ${ }^{12}$

The security forces used the excessive powers conferred on them to deal with shifta combatants and innocent civilians. The deaths of many people and the systematic 
arrests of others had direct implications for the pastoral labour force. A key informant from Merti summarised the community's perception of the shifta war as follows: '...we perished and so did our livestock. ${ }^{13}$ The livestock losses were caused by a combination of factors: raids by shifta, confiscation by government officials and animal deaths from starvation (Dahl 1979; Whittaker 2012). For example, the shifta raided and took 600 cattle and 130 camels belonging to Boru Bonsaa's family. ${ }^{14}$ Moreover, a large number of livestock and people were said to have died due to indiscriminate bombardment by the military. For example:

Kanchoro Kormayu's family owned 175 cattle and 75 camels when they were put in the security camp in Garbatula. The military machine-gunned the herd and killed his younger brother. They came out of dhaabaa without a single livestock head. ${ }^{15}$

Further, similar cases were described:

The family of Sora Galma Roba had 600 cattle and 400 goats when they were put in the security camp. During the...war their livestock was machine-gunned by the military and as result his two uncles and a cousin died. By the end of shifta war the family remained with only 5 cattle and 30 goats. ${ }^{16}$

\section{Moreover:}

The family of Jillo Hassano had 60 camels and on one fateful day, the military machine-gunned the herd and killed all the animals together with the two herders. ${ }^{17}$

One elder said, 'the numbers of livestock confiscated by government, machinegunned by the army and those that died out of starvation are almost equal. ${ }^{18}$ Another elder stated:

...I bear witness that for sure our livestock were taken away from the camps to Isiolo and other towns in Kenya by the military and the police...I have been part of the government security committee and I have witnessed it...our livestock were finished by the government. On one occasion 37 karra [A karra is an enclosure that can accommodate 100 livestock and therefore 37 karra is equivalent to 3,700 animals] of mainly cattle and small stock were taken away by the military. ${ }^{19}$

Apart from the official government confiscation, the security personnel were also accused of extorting livestock for personal benefit. A former member of the security committee said:

...we were expected to bribe them so that they would tell us when the military would come and do bombing...so each day we were told to provide them with one bull [for slaughter]...we lost many livestock also because of these daily bribes. ${ }^{20}$

The atrocities towards the civilians and their livestock and property had been reported in the media and in some cases in the official reports. While many of the official documents on the insurgency period have not been opened for public viewing, 
existing information nonetheless overwhelmingly shows that serious crimes might have been committed by the state agents. This can be gleaned from the reports of the media and the government at the time.

\section{The media and the government reports on the shifta war}

By 1964, the intensity of the conflict was heightened with the insurgency attacking government stations and towns and also preying on local communities. The government could not contain these attacks, and as a result, the residents were terrorised by both the shifta and the army. The national newspapers reported a series of violent incidents in the NFD. For example, the Daily Nation, on Wednesday, 18 November 1964, carried the following report:

Thirty-two shifta are known to be dead and about 40 wounded following a five-hour battle with Kenya security forces at the weekend. The battle took place in Merti... [when] the army and police intercepted a shifta gang of 250 deep in the gully.... ${ }^{21}$

There were reports on intensified attacks by the shifta on businesses of the local residents of Waso. For example, the Daily Nation, on Monday, 24 December 1964, reported that:

A gang of 12 to 20 shifta is believed to have attacked a shop owned by Mr. Guyo Shano and stole goods valued at $£ 52-105$. $^{22}$

The newspapers also communicated government propaganda against the shifta. In some cases, the so-called shifta reported as killed were in fact members of the public, who were alleged to have supported the shifta. The Daily Nation, on Thursday, 20 April 1965, observes:

Kenya's security forces in the north-eastern region have been given orders to shoot anyone in the area suspected to be a shifta. ${ }^{23}$

A telegram sent by the administration from Garbatula states:

It has been found out that some disloyal citizens still communicate with shifta and they have been buying food stuff and take to shifta in the bush (sic). In view of this the sub-district security committee is of the opinion that an order from Province be sought so as to give power to security forces to convict anybody found with the food stuff...outside trading centres. ${ }^{24}$

In the circumstance, the distinction between shifta combatants and the local citizens was blurred. Local people were targeted by the army on any flimsy grounds. It was common for the government security forces to demand more powers, including powers of arbitrary arrest and the confiscation of property, all under the justification of increasing security problems. In one such incident, the sub-district security staff of Garbatula requested permission to seize the pastoralists' livestock, and this was granted by a legal notice. The notice, communicated telegraphically to the Regional Government Agent in Isiolo, states, 'The sub-district Security Committee is of the opinion that the District 
Officer, Garbatula, be empowered to subordinate Course [a code for extra-judicial action] to enable the government to recover time and money already wasted'. ${ }^{25}$ Indeed, the order was calling for the government agents to use the excuse of anti-shifta activities to loot livestock from the people. The normal movement of livestock and people was restricted by the government through a Public Order Act. The Order includes details of the curfew imposed:

In exercise of the powers conferred by section 8 (1) of the Public Order Act, the Provincial Police Officer for the Eastern Province by this order directs that within the areas described by the schedule to this order and during the hours between 6.30 p.m. and in the afternoon and 6.30 a.m. of the following morning, every person shall except under and in accordance with the terms and conditions of a written permit granted by a police officer...remain indoors. ${ }^{26}$

There were three main objectives of this draconian order by the police: (1) to reduce any potential contact between the civilians and the shifta, (2) to break the morale of the hard-core shifta members so that they would surrender to the security forces and (3) to completely transform the lifestyle of the nomads from one of mobility to sedentarization. The government was aware that these changes would have an adverse impact on the pastoral economy. In one of the government reports on the shifta activities, the following observations were made in relation to these aims:

The year has seen an intensive effort by the Provincial Administration to complete the manyatazation [villagisation] plans throughout the Province, and by October 1966, the majority of the people were accommodated in villages. This concentration of the people and consequential tighter control of grazing areas no doubt had its effect on the morale of the shifta, as they were further removed from contact with their friends and relatives in the villages. ${ }^{27}$

The District Annual Report of 1967 added that 'many animals died as a result of concentration in and around the [security villages], and as was expected, famine came through the backdoor ${ }^{28}$ It is clear that the famine was not the result of natural causes but was induced by the deliberate policy of exclusion and restriction of the supply of food in the region. For the pastoralists, the death of their livestock removed their access to food. The report further added, '[a]s a result of the intensified anti-shifta campaign, many Somalis, Borana and others in Isiolo District...ran away from the area...The population of the district dropped considerably and trade was very much affected'. ${ }^{29}$

In response to the shifta activities, the government established a Special Operations Committee stationed in Isiolo to coordinate all operations in shifta areas. Unofficial sources we interviewed confirmed that the operation afforded the army a free hand to deal with not only the shifta, but also with civilians. ${ }^{30}$ The impact of these actions on the livestock economy was dire. According to the Annual Report of the Garrissa District of 1968:

...People who were known to have involved themselves in shifta activities had their property including cattle and all seized...and was confiscated and sold by public auction...So, in 1968 the cattle population, and particularly shoats [i.e. sheep and goats] had decreased considerably. ${ }^{31}$ 
The government statistics minimised the number of civilian casualties caused by army operations and were completely silent on the number of livestock looted or destroyed by the military. Instead, government statistics of 1963/1965 to 1967 reported that a total of 28,500 head of livestock had been stolen by the shifta, with less than $12 \%$ recovered. A report in the daily newspaper, The Standard, on the main impact of the shifta and the army during the 1960s and 1970s summarises the situation at the time: '...survivors of the drought and the war were left very poor. Many women [were] widowed, children orphaned and whole families separated' ${ }^{32}$ The overall picture is that the livestock economy was severely affected by the war. The confiscation of livestock was a deliberate move by the government to punish the Waso Borana in response to the army's high casualties caused by land mines laid by the insurgency. A government report added:

The month saw increased shifta activities and introduction of landmines, which resulted in over 490 head of cattle being confiscated and more destroyed by security forces, as a punishment to the hostile tribesmen. ${ }^{33}$

The District Commissioner (R.K. Musyoki), Isiolo, ordered as follows:

That $10 \%$ of the stock seized from the Kubi Turkana Manyatta be confiscated. All seized stock belonging to persons who assisted shifta personally during the period of 18th to 20th March 1965 to be confiscated. All seized stock belonging to the shifta leader Mohamed Awl and any other shifta to be confiscated. All the proceeds of the sale of such confiscated stock to be paid into the SD. (A) Act Fund. ${ }^{34}$

As the war gradually came to an end and peace was declared between Somalia and Kenya $^{35}$, the local pastoralists were informed that they could claim compensation for the livestock destroyed or stolen. Though we found no evidence in the archives that the victims were compensated, there are detailed correspondences where the complaints by the pastoralists were filed. This material would be reported elsewhere, suffice to summarise some key incidents. More than 150 herders presented claims to the government. The Borana herd owner Boru Soraa was one of those who presented such claims to the District Commissioner, Isiolo. His letter states, 'This is to inform you that in 1965 my 110 head of cattle were taken away by government due to the problem of shifta, I am asking for compensation. ${ }^{36}$ Mr. Halake Guyo reported that on 9 November 1966 the security forces confiscated 400 cattle at Moliti (Kulamawe). Some claims were submitted by women. For example, Asha Warsame Farah (a Somali) claimed that 200 sheep and goats, 1,100 cattle and 30 donkeys belonging to her had been taken by the government security staff in 1967. The correspondences also claim a large loss of property in terms of destruction of houses. A group of 205 families sent their claims to the District Commissioner, reporting the loss of a total of 17,436 cattle, while eight families reported the loss of 2,474 sheep and goats, 30 camels and 197 donkeys, and the destructions of businesses. ${ }^{37}$ The outcome of the insurgency and the government counter-insurgency was severe on the pastoral economy, the effects of which is still being felt some 44 years after the war ended. 


\section{The pastoral economy forty-four years later}

By the end of the shifta war, two species of livestock had almost disappeared: these were small stock and the camels (Dahl 1979). Hogg (1985) estimates that between 1963 and 1970, the camel population declined by $95 \%$ and the small stock population by $90 \%$. The camel population declined sharply, partly because the Sakuye camel keepers fled to Somalia with their herds. However, the camel herds perished as a result of tsetse fly effects that caused huge mortalities. Their herds of small stock were decimated because they were frequently slaughtered to provide food for starving families and eaten by the security forces. One elder summarised the status of the small stock herds and camel population by the end of the shifta war:

At the end of dhaabaa the sight of small stock became a rarity and was a sort of amusement and attracted a lot of attention. People would shout across the villages and tell each other 'come out and see some goats' as if they had never seen it before or as if it were some kind of a new creature that had come into existence. For sure, this species almost disappeared. ${ }^{38}$

The elders interviewed reported that nearly all the Waso pastoral families had been rendered stockless within a very short period of time. Our household data confirm the collapse of the livestock population and pastoral economy in the aftermath of the shifta insurgency (1968) across all three communities. Camels were the species most affected by the conflict. At the end of insurgency in 1968, the mean camel holding of Kulamawe was 7.2 animals per household, and they registered the highest loss, of $97.5 \%$. The mean camel holding in Merti was 11.5 animals, showing a decline of $93 \%$. Kinna had a mean of 25 camels per household, registering a decline of $80.2 \%$. The small stock holdings showed a decline across the three sites averaging $92.3 \%$, while the cattle population declined by $89.6 \%$.

The livestock populations during the selected years (1984 to 2007) never reached the levels of the pre-shifta period (Figure 2a,b,c). The pastoral economy has persisted at lower population levels and showed a minor recovery at a rate of about $0.4 \%$ per year. The comparisons of the herds by species and by site showed some variation, but overall, there was no recovery, which the communities blamed on persistent banditry since the shifta war and frequent droughts.

\section{Impact of banditry and recurrent droughts on pastoral economy}

The proliferation of small arms had transformed the conflict from a regional war to local banditry after the emergence of Somali bandits involved in organised poaching, mainly elephants for their ivory (Daleo 1979). This caused high levels of local insecurity in the Waso region. The economic agendas of the poachers are central to continuation of armed conflicts fuelled by increase in the supply of small arms (Collier and Hoeffler 2004). Banditry on the highway, night attacks on households or businesses and attacks on ordinary travellers disrupted the recovery. One resident of Kulamawe reported the following event that happened after the end of shifta war:

...If they spot businessmen they kill them and loot the goods they are transporting. This is how the Waso Borana lost all their prominent businessmen. I can count up to 20 businessmen killed by bandits. ${ }^{39}$ 
The bandits not only stole goods but were also brutal to the community. A man narrated the following incident:

...shifta tied together 15-20 men and beat them to death.... Some of my friends were tied together and burnt to death. ${ }^{40}$

A resident of Rapsu village in Kinna narrated a harrowing experience:

One day we were walking from Rapsu irrigation scheme to Kinna. Half way through the journey some armed Somali men stopped us. We were five men, two women and a girl of 12 years. They pointed guns at our heads and tied all the men together.

They told us to watch as they raped the women and the little girl. We felt very helpless, we wanted to die.... ${ }^{41}$

These narratives show unforgettable 'social and economic wounds' left in the Kinna community. It is a story where the problem was partly exacerbated by the weakness of state surveillance in remote areas, which prevented the eradication of banditry. For the Waso Borana, the insurgency and counter-insurgency were the root causes of pastoral poverty. An elder from Kinna reported:

Our problem is rooted in insecurity. I can confidently say that our current poverty is caused by insecurity. If you ask all the households in Kinna today, you will not get a single family that has not lost their livestock or a member of their family to cattle raiders and highway bandits. ${ }^{42}$

Banditry continued into the early 1990s. According to another elder from Kulamawe:

On 19th May 1992 the Somali bandits attacked our village in Kulamawe and made away with a total of 400 cattle. My family lost 80 cattle and my brother's leg was amputated due to the bullet wounds received during the attack. ${ }^{43}$

Another elder from Merti said:

Since the end of shifta war it is over 40 years and the killings continue. Recently, they raided our family's herd and injured my brother. Even this elder sitting next to you lost all his livestock to Somali bandits. ${ }^{44}$

Our informants reported strong links between sustained banditry and poverty. This is what one other elder said:

Three things have refused to leave us: hunger, poverty and war. It is impossible for us to recover from poverty because, for example, a person who was rich yesterday becomes stockless overnight due to the cattle raid.... If this is our everyday life, how [does one] expect us to come out of poverty ? $^{45}$

These narratives reflect desperation and vulnerability of the community suffering from sustained conflicts. The sustained insecurity and frequent droughts would explain the rather low level of pastoral herd recovery after the shifta war. 
The insecurity forced the livestock to be grazed within a restricted security zones (Dahl 1979; Hogg 1990; Baxter 2001). These areas were prone to overstocking, increasing the vulnerability of herds to recurrent droughts. According to a group discussion:

The Somalis have made $100 \mathrm{~km}$ stretch of land that borders their territories unsafe for us and our livestock. Our livestock cannot graze more than 5 kilometres from the town. If we attempt to graze further than this our livestock will not return and that is also the end of the herders' lives....

Even when peace returned, the Somali herds encroached on pastures traditionally reserved for the dry season. The effect is massive livestock losses during drought periods. During the drought of 1984, locally referred to as oolaa Katitinii (the drought year when herds moved to Katitini in Kitui District), there were massive losses of livestock. The most recent drought was that of 2005 to 2006, locally referred to as oolaa hammeena (the drought that brought diseases). The key informants reported several cases where households lost nearly all their livestock. A resident of Kulamawe, Mr. Wario Jaldesa, reported the following about the 2006 drought:

At the onset of the drought period, I moved my livestock from Kulamawe to Galana (in Merti). I had 500 head of cattle and most of them perished there. The main cause of the deaths was the spread of sombeesa [bovine pleuro-pneumonia].... I am not the only one who suffered the losses, many people in Waso suffered like me.

Another factor that undermines herd growth is that pastoralists are increasingly settling down as a result of the need to access social amenities such as schools. Some of the settled groups keep livestock near their homesteads, with the livestock grazing only a few kilometres from the settlement. This is partly contributed by loss of labour force for herding. The withdrawing of child labour from herding to formal education means that herders must now rely on hired labour. The herders argued that hired labourers do not have the same commitment to the livestock as the owners have. The loss of commitment and adequate pastoral labour is considered by the three communities to be an additional cause of the lack of recovery.

\section{Conclusions}

In this article, we have dealt with the impact of post-independence armed insurgency, counter-insurgency and the post-shifta banditry on the pastoral economy of the Waso Borana. This study had examined one aspect of the impact: the pastoral production. The shifta insurgency and the Kenyan army's counter-insurgency had left legacies of socio-economic and personal traumas in the minds of some of the residents of the former NFD. This is a subject matter that in the official circles was hushed until the 1990s. The time is now ripe to conduct a post-mortem analysis of the insurgency war and its local and regional implications, particularly its transforming effects on the pastoralist livelihood strategies. We have shown that the contemporary conflicts in Waso are a continuation of past armed conflicts coupled with droughts. This situation is illustrated by two features of the conflicts. First, although the shifta activities were driven in 
part by local grievances, they were a reflection of the unsettled borders and frontiers in the Horn of Africa resulting from political instability. Second, the extension of armed insurgency and counter-insurgency on the pastoral economy has led to the proliferation of small arms in the region. The shifta war provides an important historical benchmark for understanding the politics as well as legacies of poverty and insecurity that have locked the region into continued instability for 44 years after the main conflict had waned. Our study has merely scratched the surface of the long-term consequences of the post-independence insurgencies and counter-insurgency on the pastoral economy in northern Kenya, a subject which no doubt deserves more comprehensive analysis by historians and anthropologists in the future.

\section{Endnotes}

${ }^{1}$ The six districts (comprising Isiolo, Marsabit, Moyale, Wajir, Garissa and Mandera) were administered separately from the rest of the country between 1909 and 1963. They were 'closed' from the rest of the country through district ordinances that obliged travellers to carry 'passes' when travelling both within and outside the region (see Mburu 2005). The NFD shared international borders with Somalia and Ethiopia.

${ }^{2}$ The word 'shifta' (bandits) was the official term used by the Kenyan Government for the secessionist insurgency of the time. The term, probably derived from Amharic, is an old expression used when referring to general types of outlaws.

${ }^{3}$ Walters PE to Small AC. 1949. Handing over report: Garissa District, KNA/DC/ GRA/2/2.

${ }^{4}$ Immediately, the ban on political parties was lifted and new political parties were formed, the majority of whom championed the union with Somalia. These included the pro-secessionist Northern Province People's Progressive Party, the Northern Province People's National Union and the anti-secessionist parties of the Galla Political Union and Northern Peoples United Association.

${ }^{5}$ Kenya gained independence on 12 December 1963.

${ }^{6}$ The Marsabit and Moyale Borana Oromo and Gabbra were among the proindependence pastoral groups.

${ }^{7}$ It was clearly not practical to try and find the exact source of livestock acquisition over such a long period. It was possible that some of the stock reported could have been raided from other communities, in which case the new owners would be unlikely to reveal their sources. Because of the uncertainty, our data is not ideal for modelling herd growth with assumed rates of births, deaths and offtake (see Dahl and Hjort 1976; Oba 2001 for the assumptions made in such models).

${ }^{8}$ Interview with Huqa Wario in Kulamawe, 30 September 2007.

${ }^{9}$ Interview with Mohamed Koricha in Merti, 2 November 2007.

${ }^{10}$ Paul Baxter (1954, p. 136) cites such an illuminating moment, which has remained a popular story, about one foolish pastoralist. A wealthy young Moslem Borana named Hapi Bonaya made unacceptable jibes against nature. In 1949, during a brief dry season, he and others experienced milk shortages from the herds. This was followed by another period of deluge, hence his curious 'jibes' regarding the surplus milk for which they had no immediate use. Hapi, who fancied himself as a comic (as Baxter explains), took a full container of milk and staged the following scene, with Hapi playing both parts of the 
drama: Hapi: 'where have you been to all this long time? Hunger has been killing us'. Milk: 'In the stomach of God'. Hapi: 'Return to God then', with which remark, Hapi kicked over [the milk container] and beat the milk with a stick while it drained into the sand. The story had a sad ending. Hapi soon after became a perpetual poor.

${ }^{11}$ Interview with Godana Waqo in Kulamawe in August 2007.

${ }^{12}$ Interview with Sama Halakhe in Kinna on 1 August 2007.

${ }^{13}$ Interview with Jattani Duba in Marti in 2007.

${ }^{14}$ Interview with Mohamed Koricha Merti August 2007.

${ }^{15}$ Interview with Mohamed Koricha Merti August 2007.

${ }^{16}$ Interview with Mohamed Koricha Merti August 2007.

${ }^{17}$ Group discussion in Merti in September 2007.

${ }^{18}$ Group discussion in Merti in September 2007

${ }^{19}$ Group discussion in Merti in September 2007.

${ }^{20}$ Group discussion in Merti in September 2007.

${ }^{21}$ The Daily Nation, Wednesday 18 November 1964

${ }^{22}$ The Daily Nation, Monday 24 December 1964

${ }^{23}$ The Daily Nation, Thursday 20 April 1965

${ }^{24}$ Telegram, G/Tula EN 24/13 of 1966.

${ }^{25}$ Telegram EN 24/12 S. 225/66, Legal Notice no. 263 (Para 132 B) on stock seizer.

${ }^{26}$ Public Order Act (Cap. 56) Laws of Kenya 1962 (Revised). Curfew orders signed by HM Ochieng, Provincial Police Officer, Eastern Province.

${ }^{27}$ Operations against shifta: An appreciation of statistics the fourth year, BB/12/26, vol. 1 1.11.66 to 31.10.67.

${ }^{28}$ Isiolo District Annual Report 1967, RU P/P/1.

${ }^{29}$ Annual Confidential Report 1967: Isiolo District.

${ }^{30}$ Interview with an ex-army official who participated in the operations against the shifta.

${ }^{31}$ Garissa District Annual Report 1968, RE/8/22.

${ }^{32}$ Letter from DC Isiolo, 10 March 1967 to PC Eastern referenced ADM 15/18/20.

${ }^{33}$ Extract of the order dated 24 March 1965.

${ }^{34}$ The peace was negotiated by President Kenneth Kaunda of Zambia dubbed the Arusha Declaration at a seating in the Tanzanian town of Arush. The peace negotiations were attended by the Kenyan and the Somali delegates.

${ }^{35}$ Compensation claims for livestock and properties lost during the shifta menace, $\mathrm{KNA} / \mathrm{DC} / \mathrm{ISO} / 4 / 7 / 4$.

${ }^{36}$ Compensation claims for livestock and properties lost during the shifta menace, $\mathrm{KNA} / \mathrm{DC} / \mathrm{ISO} / 4 / 7 / 4$.

${ }^{37}$ Group discussion in Kulamawe August 2007.

${ }^{38}$ Interview with Sama Halakhe in Kinna on 1 August 2007.

${ }^{39}$ Group discussion in Kulamawe August 2007.

${ }^{40}$ Interview with Sama Halakhe in Kinna on 1 August 2007.

${ }^{41}$ Group discussion in Kinna on 1 August 2007.

${ }^{42}$ Group discussion in Kinna on 1 August 2007.

${ }^{43}$ Interview with Jilo Tacho in Kulamawe, 18 September 2007.

${ }^{44}$ Group discussion in Merti in September 2007.

${ }^{45}$ Group discussion in Merti in September 2007. 


\section{Competing interests}

The authors declare that they have no competing interests.

\section{Authors' contributions}

ZKK designed, collected the data and drafted the manuscript. GO was responsible for the revision. Both authors read and approved the final manuscript.

\section{Authors' information}

ZKK graduated in 2010 with a PhD in development studies from the Norwegian University of Life Sciences. GO is a professor at the Department of International Environment and Development Studies, NORAGRIC, Oslo, Norway. GO is the author of Nomads in the Shadows of Empires (BRILL, 2013).

\section{Acknowledgements}

The authors thank all those who supported the study and in particular the men and women from Kinna, Kulamawe and Merti whose voices are captured in this article.

Received: 13 December 2012 Accepted: 26 May 2013

Published: 28 June 2013

\section{References}

Baxter, PTW. 1954. Social organization of the Galla of northern Kenya, PhD thesis. University of Oxford.

Baxter, PTW. 1966. Acceptance and rejection of Islam among the Borana of the Northern Frontier District of Kenya. In Islam in tropical Africa, ed. IM Lewis, 233-250. London: International African Institute.

Baxter, PTW. 2001. Immediate problems: An overview from a distance. In African pastoralism: Conflict, institutions and government, ed. MARM Saleh, T Dietz, and AGM Ahmed, 235-246. London: Pluto Press.

Brons, MH. 2001. Somalia, society, sovereignty and state: From statelessness to statelessness? Utrecht: International Books.

Buchanan-Smith, M, and J Lind. 2005. Armed violence and poverty in northern Kenya: A case study for the Armed

Violence and Poverty Initiative. Bradford: Centre for International Cooperation and Security, University of Bradford.

Castagno, AA. 1964. The Somali-Kenya controversy: Implications for the future. The Journal of Modern African Studies 2: $165-168$.

Collier, P, and A Hoeffler. 2004. Greed and grievance in civil wars. Oxford Economic Papers 56(4): 563-595.

Dahl, G. 1979. The suffering grass: Subsistence and society of Waso Borana. Stockholm: Department of Social Anthropology, University of Stockholm.

Dahl, G, and A Hjort. 1976. Having herds: Pastoral herd growth and household economy. Stockholm: Stockholm Studies in Social Anthropology.

Dahl, G, and S Sandford. 1978. Which way to go: A study of people and pastoralism in Isiolo district of Kenya. Ottawa: Canadian International Development Agency.

Daleo, PT. 1979. The Somali role in organized poaching in northeastern Kenya, c. 1909-1939. International Journal of African Historical Studies 12: 472-482.

de Waal, A. 1997. Famine crimes: Politics and the disaster relief industry in Africa. Oxford: James Currey.

Drysdale, J. 1964. The Somali dispute. New York: Fredrick A. Praeger.

Egal, MHI. 1968. Somalia: Nomadic individualism and the rule of law. African Affairs 67: 219-226.

Farer, T. 1979. War clouds on the Horn of Africa: The widening storm. Washington DC: Carnegie Endowment.

Hammond, J. 1999. Fire from the ashes: A chronicle of the revolution in Tigray, Ethiopia, 1975-1991. Lawrenceville, NJ: Red Sea Press.

Hendrickson, D, J Amon, and R Means. 1996. Livestock raiding among the pastoral Turkana of Kenya: Redistribution, predation and the links to famine. Institute of Development Studies Bulletin 27(3): 17-30.

Hess, RL. 1966. Italian colonialism in Somalia. Chicago: University of Chicago Press.

Hjort, A. 1979. Savanna town: Rural ties and urban opportunities in northern Kenya. Stockholm: Department of Social Studies, University of Stockholm.

Hogg, R. 1980. Pastoralism and impoverishment: The case of the Isiolo Boran of northern Kenya. Disasters 4(3): 299-310.

Hogg, R. 1985. Re-stocking pastoralists in Kenya: A strategy for relief and rehabilitation, ODI, Pastoral Development Network, Paper 19 (c). London: Overseas Development Institute.

Hogg, R. 1986. The new pastoralism: Poverty and dependency in northern Kenya. Africa 56: 319-333.

Hogg, R. 1990. The politics of changing property rights among Isiolo Boran pastoralists in northern Kenya. In Property, poverty and people: Changing rights in property and problems of pastoral development, ed. PTW Baxter and R Hogg, 20-31. Manchester: Department of Social Anthropology and International Development Centre, University of Manchester.

Hoskyns, C. 1969. The Ethiopian-Somali-Kenyan dispute 1960-67: Documents. Dar es Salaam: Oxford University Press for the Institute of Public Administration, University College Dar es Salaam.

James, W. 2007. War and survival in Sudan's frontierlands: Voices from the Blue Nile. Oxford: Oxford University Press.

Kaimba, GK, BK Njehia, and AY Guliye. 2011. Effects of cattle rustling and household characteristics on migration decisions and herd size amongst pastoralists in Baringo District, Kenya. Pastoralism: Research, Policy and Practice 1: 18. http://www.pastoralismjournal.com/content/1/1/18.

Lewis, IM. 1963. The problem of Northern Frontier District of Kenya, Race 5:48-60.

Lewis, IM. 2000. A modern history of Somalia. Oxford: James Currey.

Lewis, IM. 2004. Visible and invisible differences: The Somali paradox. Africa 74: 489-515.

Markakis, J. 1993. In Conflict and the decline of pastoralism in the Horn of Africa, ed. J Markakis. London: Macmillan Press.

Markakis, J. 1998. Resource conflict in the Horn of Africa. PRIO: Oslo.

Markakis, J. 2010. Ethiopia: The last two frontiers. London: James Currey.

Mburu, N. 2005. Bandits on the border: The last frontier in the search for Somali unity. Trenton, NJ: Red Sea Press. 
McCabe, JT. 2004. Cattle brings us to our enemies: Turkana ecology, politics, and raiding in a disequilibrium system. Ann Arbor: The University of Michigan Press.

McEwen, AC. 1971. International boundaries of East Africa. Oxford: Clarendon.

Miall, H. 2004. Conflict transformation: A multi-dimensional task. http://www.berghof-handbook.net/documents/ publications/miall_handbook.pdf. Accessed 15 June 2013.

Mkutu, KA. 2006. Small arms and light weapons among pastoral groups in the Kenya-Uganda border area. African Affairs 106(422): 47-70. doi:10.1093/afraf/ad1002.

Mkutu, KA. 2008. Guns and governance in the Rift valley: Pastoralist conflict and small arms. James Currey: Oxford University Press.

Oba, G. 1993. Ecological factors in land use conflicts, land administration and food insecurity in Turkana Kenya. ODI Pastoral Network: Issue 32a. http://www.odi.org.uk/sites/odi.org.uk/files/odi-assets/publications-opinion-files/5389. pdf. Accessed 23 November 2012.

Oba, G. 2001. The effect of multiple droughts on cattle in Obbu, northern Kenya. J Arid Environ 49: 375-386.

Pieter, L. 1964. Only hyenas laugh. London: Michael Joseph.

Schilling, J, FEO Opiyo, and J Scheffran. 2012. Raiding pastoral livelihoods: Motives and effects of violent conflict in north-western Kenya. Pastoralism: Research, Policy and Practice 2: 25. http://www.pastoralismjournal.com/content/ 2/1/25 Accessed on 6 December 2012.

Schlee, G, and E Watson. 2009. Changing identifications and alliances in North-east Africa: Ethiopia and Kenya, vol. 1. London: Berghahn Books.

The Earl of Lytton. 1966. The stolen desert: A study of Uhuru in Northeast Africa. London: McDonald.

Touval, S. 1972. The Boundary politics of independent Africa. Cambridge: Harvard University Press.

Turton, ER. 1972. Somali resistance Somali political activity in Kenya 1893-1960. The Journal of African History 13(1): 119-143.

Whittaker, HA. 2012. The socioeconomic dynamics of the shifta conflict in Kenya, c. 1963-8. The Journal of African History 53: 391-408.

doi:10.1186/2041-7136-3-14

Cite this article as: Khalif and Oba: 'Gaafa dhaabaa - the period of stop': Narrating impacts of shifta insurgency on pastoral economy in northern Kenya, c. 1963 to 2007. Pastoralism: Research, Policy and Practice 2013 3:14.

\section{Submit your manuscript to a SpringerOpen ${ }^{\circ}$ journal and benefit from:}

- Convenient online submission

Rigorous peer review

- Immediate publication on acceptance

- Open access: articles freely available online

- High visibility within the field

- Retaining the copyright to your article

Submit your next manuscript at $\boldsymbol{\sim}$ springeropen.com 